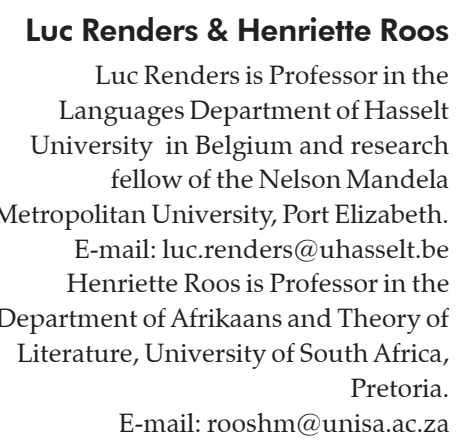

\title{
Editorial \\ The Congo in Literature
}

The year 2008 marks the hundredth anniversary of King Leopold II's relinquishment of his Crown colony on the equator in favour of the Belgian State. In modern Belgium there were hardly any celebrations of this centenary. This is not surprising as Belgium was a reluctant partner in a hastily arranged marriage of convenience in 1908. The colonial link was forged when Leopold II was granted sovereign rule over the Congo at the Conference of Berlin in 1885. From 1885 to 1908 the Congo remained the fiefdom of Leopold II, an acquisition named the Congo Free State. When the inhuman treatment of the Congolese population was revealed, mainly through the sustained efforts of Edmund Dene Morel, a British activist, and Roger Casement, the British Consul to the Congo, Leopold II was forced to hand over the Congo to the Belgian State. On 15 November 1908 the colony was renamed the Belgian Congo.

The Congo remained under Belgian rule until 30 June 1960. Initially the Belgian politicians and population were rather sceptical about their African colony but gradually they became fervent supporters of the colonial project. The infrastructure of the Congo was systematically developed and the Congolese population was integrated into the colonial system.

The years following the independence celebrations and the murder of Patrice Lumumba were marked by violent upheavals and political instability. In $1965 \mathrm{Mobu}-$ tu Seso Seku assumed power in the Congolese state. He ruled the Congo until 1997, exploited it as his personal possession and brought it to the brink of economic meltdown. His government was overthrown by Laurent-Désiré Kabila, who himself was killed in a failed coup. Kabila was succeeded by his son Joseph, who is still the head of the Congolese state. After the genocide in Rwanda in 1994 the political and military situations have deteriorated rapidly, especially in the Eastern Congo. The local people have been the victims of the perpetual ethnic, economic and political conflict.

The history of the Congo has been, since the beginning of the colonisation, a tragic and extremely violent one. Its abundant natural resources seem a curse rather than a blessing; foreign and neocolonial powers have ceaselessly been trying to grab a share of the profits. In November 2008 the fighting in Eastern Congo, as part of an ongoing 
war, is once again making headlines - the Congo does not seem to be any better off than in 1908.

The centenary of the Belgian colonisation provided an appropriate opportunity to take stock of the literary production of and about the Congo. The conference "Congo in literature/in de literatuur/dans la littérature" was hosted by Hasselt University in Belgium from 14 to 18 July 2008 with the aim of putting this corpus of literary works in the spotlight.

From a Flemish and Walloon perspective, Congo literature is not widely known and even less studied. Academic interest in Dutch or French literary texts on the Congo is almost non-existent in spite of the fact that the Congo played such an important role in twentieth century Belgian history. A comprehensive knowledge of Congo literature offers the opportunity of rediscovering as well as re-appraising the past. A critical analysis of the colonial presence of Belgium in the Congo from a postcolonial perspective is also urgently required. From a purely literary-historical perspective, it is appropriate to re-assess the Flemish and Walloon literature on the Congo. Texts critical of the colonial project deserve particular attention. Through their authentic nature and persuasive tone a valuable contribution to Flemish and Walloon literature is made.

Moreover, there is the literature emanating from the Congo itself. Literary texts are not only narrated and written in the various indigenous languages, but are also produced and published in French. Since the inception of the colonial enterprise French has been the medium of instruction in the educational system of the Congo. It still remains the language of choice for a large number of Congolese authors, even when they, as is quite often the case nowadays, write from abroad. The different perspectives, which can often be discerned when comparing expatriate Congolese writers and those living in the Congo, are intriguing, and alert the reader to the complexities of Congolese literature and its portrayal of the Congo.

However, Congo literature also displays a distinctly international flavour. Writers representing different countries and writing in a variety of languages have been fascinated by the Congo for quite some time. Joseph Conrad's Heart of Darkness has established an almost global literary tradition. Heart of Darkness still resonates within various intertextual discourses, also in recent Afrikaans literature. The dystopian vision of a future South Africa that Eben Venter portrays in his novel Horrelpoot (Trencherman), acquires an additional apocalyptic dimension via references to Heart of Darkness. The novel Equatoria by Tom Dreyer is also indebted to Conrad and the Congo.

One of the objectives of the "Congo in literature/in de literatuur / dans la littérature" conference was to transcend language barriers by exploring the literature on the Congo written in different languages. Academics often only focus on texts written in their own language, but the study of Congo literature especially benefits from a comparative approach. A comparative analysis generates an intensive exchange of 
ideas and leads to new insights. The participants at the conference experienced this first hand.

The articles published in this special issue of Tydskrif vir Letterkunde devoted to Congo literature, are testimony to the wide range of authors, books and topics which were discussed at the "Congo in literature" conference. When reading these contributions, one is struck by the recurring references to particular books, writers, motifs and themes. A strong network of relationships is thus established. This illustrates not only how enriching a comparative approach to Congo literature can be, but also how much scope remains for further research.

15 November 2008 